\title{
PENINGKATAN AKTIVITAS BELAJAR MATEMATIKA SISWA KELAS VII MTSN1 KOTA BENGKULU DENGAN MODEL PEMBELAJARAN TALKING STICK
}

\author{
${ }^{1}$ Nelvi Noviza, ${ }^{2}$ Drs. M. Fachruddin S, ${ }^{3}$ Drs. Rusdi \\ 1,2,3 Program Studi Pendidikan Matematika JPMIPA FKIP Universitas Bengkulu \\ Email: 1nelvinoviza28@yahoo.co.id, ${ }^{2}$ m.fachruddin.S@gmail.com, ${ }^{3}$ rusdipendmat12@gmail.com
}

\begin{abstract}
Abstrak
Penelitian ini bertujuan untuk mengetahui peningkatan aktivitas belajar matematika siswa kelas VII MTs N1 Kota Bengkulu dengan model pembelajaran talking stick. Jenis penelitian ini adalah quasi eksperimen. Penelitian ini dilakukan di MTs N 1 Kota Bengkulu tahun ajaran 2016/2017. Sampel diambil dengan teknik purposive sampling sehingga diperoleh bahwa kelas VII $_{\mathrm{C}}$ sebagai kelas eksperimen dan kelas $\mathrm{VII}_{\mathrm{B}}$ sebagai kelas Kontrol. Selama proses pembelajaran siswa terlihat sangat aktif berdiskusi kelompok kemudian siswa antusisas mengikuti tahap tongkat bergilir diiringi musik. Disimpulkan bahwa terjadi peningkatan aktivitas belajar matematika siswa kelas VII MTsN1 Kota Bengkulu menggunakan model pembelajaran talking stick.
\end{abstract}

Kata Kunci: model pembelajaran talking stick, aktivitas belajar

\begin{abstract}
This research aimed to find increased mathematic student learning activity in the first grade students of MTsN1 Kota Bengkulu which use talking stick teaching model. Type of this research is quasi experiment. This research conducted in MTsN1 Kota Bengkulu academic year 2016/2017. The sample was taken by purposive sampling technique so that VIIc taken as experiment class and VIIb as control class. During student learning looks very active discussion group then students enthusiastically follow the talking stick rolling accompany music. It was concludy that there was an increase in student learning activity of mathematic in the first grade students of MTs N1 Kota Bengkulu which use talking stick teaching model.
\end{abstract}

Keywords: talking stick teaching model, activity

\section{PENDAHULUAN}

Matematika berkenaan dengan ide-ide dan konsep-konsep yang abstrak dan tersusun secara hierarki dan penalarannya deduktif sehingga belajar matematika tidak boleh ada langkah atau tahapan konsep yang dilewati. Matematika hendaknya dipelajari secara sistematis dan teratur serta harus disajikan dengan struktur yang jelas dan harus disesuaikan dengan perkembangan intelektual peserta didik serta kemampuan prasyarat yang telah dimilikinya. Dengan demikian pembelajaran matematika akan terlaksana secara efektif dan efisien sehingga hasil belajar menjadi lebih baik.

Berdasarkan observasi dan wawancara yang dilakukan peneliti kepada beberapa peserta didik di MTsN1 Kota Bengkulu sebagian besar peserta didik yang di wawancarai tidak menyukai pelajaran matematika dengan alasan matematika merupakan pelajaran yang sangat sulit, membosankan, dan tidak menarik. Dengan demikian sebagai konsekuensinya, aktivitas belajar siswa tidak terjadi sesuai yang diharapkan.

Masalah yang timbul dalam proses belajar mengajar disebabkan kurangnya hubungan yang komunikatif antara guru dan peserta didik serta peserta didik dengan peserta didik lainnya, sehingga proses interaksi menjadi vakum, padahal proses belajar mengajar dipengaruhi oleh perilaku saling interaksi, peserta didik sebagai subyek didik adalah yang merencanakan dan ia sendiri yang melaksanakan belajar. Model pembelajaran yang kurang efektif dan efisien, menyebabkan tidak seimbangnya kemampuan kognitif, afektif, dan psikomotorik. Model pembelajaran yang monoton akan menyebabkan peserta 
didik merasa bosan dan memiliki motivasi belajar yang rendah sehingga peserta didik sangat pasif selama proses pembelajaran.

Dalam hal ini untuk mengatasi masalah yang telah dikemukakan salah satu model pembelajaran yang dapat digunakan untuk meningkatkan aktivitas belajar matematika peserta didik adalah model pembelajaran talking stick. Dalam model pembelajaran ini peserta didik dituntut untuk aktif mengikuti proses pembelajaran sehingga pembelajaran matematika tidak berpusat pada guru melainkan peserta didik ikut berperan aktif.

Lestari \& Yudhanegara (2015: 72) mengatakan bahwa model pembelajaran talking stick merupakan model pembelajaran dengan bantuan tongkat dan musik pengiring. Peserta didik yang memegang tongkat saat musik berhenti dimainkan harus menjawab pertanyaan yang diajukan, demikian seterusnya. Dengan kata lain, model pembelajaran talking stick mendorong peserta didik untuk berani mengemukakan pendapat menggunakan sebuah tongkat sebagai alat penunjuk giliran. Peserta didik yang mendapat tongkat akan diberi pertanyaan dan harus menjawabnya. Kemudian secara estafet tongkat tersebut berpindah ke tangan peserta didik lainnya secara bergiliran. Demikian seterusnya sampai seluruh peserta didik mendapat tongkat dan berhasil menjawab pertanyaan.

Penggunaan model pembelajaran talking stick ini telah mampu memberikan kontribusi dalam dunia pendidikan, hal ini dapat dilihat dari hasil penelitian yang dilakukan oleh Suryo Hartanto (2016) yang menunjukkan bahwa model pembelajaran talking stick dapat meningkatkan hasil belajar peserta didik kelas VIII SMP Negeri 11 Batam.

Berdasarkan latar belakang yang telah diuraikan, maka rumusan masalah dari penelitian ini adalah apakah terjadi peningkatan aktivitas belajar matematika siswa kelas VII MTs N1 Kota Bengkulu dengan menggunakan model pembelajaran talking stick? Berdasarkan rumusan masalah di atas, maka tujuan dari penelitian ini adalah untuk mengetahui peningkatan aktivitas belajar matematika siswa kelas VII MTs N1 Kota
Bengkulu dengan menggunakan model pembelajaran talking stick.

\section{METODE PENELITIAN Jenis Penelitian}

Jenis penelitian yang digunakan dalam penelitian ini adalah penelitian eksperimen semu (quasi eksperimen). Menurut Sugiyono (2014: 77) quasi eksperimen adalah penelitian yang mempunyai kelompok kontrol, tetapi tidak dapat berfungsi sepenuhnya untuk mengontrol variabel-variabel luar yang mempengaruhi pelaksanaan eksperimen.

\section{Subjek Penelitian}

Populasi dalam penelitian ini adalah seluruh siswa Kelas VII MTsN 1 Kota Bengkulu berjumlah 273 siswa yang terdiri dari 8 kelas. Peneliti memilih dua kelas dari 8 kelas yang ada sebagai sampel penelitian dan nilai rata-rata yang hampir sama yaitu $\mathrm{VII}_{B}$ sebagai kelas kontrol dan kelas $\mathrm{VII}_{\mathrm{C}}$ sebagai kelas eksperimen dengan cara random sampling.

\section{Model Pembelajaran Talking Stick}

Menurut Supriyanto (2013: 109) pembelajaran dengan model talking stick mendorong peserta didik untuk berani mengemukakan pendapat. Menurut Lestari \& Yudhanegara (2015: 37) talking stick adalah model pembelajaran dengan bantuan tongkat dan musik pengiring, peserta didik yang memegang tongkat saat musik berhenti dimainkan harus menjawab pertanyaan yang diajukan, demikian seterusnya.

Menurut Huda (2013: 224) talking stick adalah metode yang digunakan oleh penduduk asli amerika untuk mengajak semua orang berbicara atau menyampaikan pendapat dalam suatu forum (pertemuan antarsuku). Kini metode ini sudah digunakan sebagai metode pembelajaran ruang kelas. Dalam penerapan metode talking stick ini guru membagi kelas menjadi kelompok-kelompok dengan anggota 5 atau 6 peserta didik yang heterogen. Kelompok dibentuk dengan pertimbangan akrab, kecerdasan, persahabatan atau minat yang berbeda. Metode ini cocok digunakan untuk semua kelas dan semua tingkatan umur. 
Berdasarkan beberapa pendapat di atas maka disimpulkan model pembelajaran talking stick adalah model pembelajaran yang mendorong peserta didik untuk mengemukakan pendapat dengan tongkat penunjuk peserta didik yang harus mengemukakan pendapat dan musik sebagai pengiring.

\section{HASIL}

\section{Proses Model Pembelajaran Talking Stick}

Berdasarkan hasil penelitian pada proses pembelajaran dengan model pembelajaran talking stick siswa menjadi lebih aktif dalam pembelajaran, tercipta suasana kelas yang tidak membosankan dengan adanya tongkat bergulir yang diiringi musik siswa sangat antusias untuk memahami materi karena terlihat siswa sangat kompetitif.

Pembelajaran dengan menggunakan model pembelajaran talking stick terdapat tujuh langkah yang harus dilakukan siswa dan guru. Langkah pertama yaitu persiapan, dimana langkah ini guru mempersiapkan tongkat berwarna biru, handphone untuk musik dan speaker untuk pengeras suara dan spidol serta mengecek infokus yang telah terpasang di Kelas VII $_{C}$. Setelah semua peralatan siap dan siswa terlihat sudah siap untuk belajar maka langkah kedua yaitu penyampaian materi, dimana langkah ini guru menyampaikan materi didepan kelas dan menuliskan hal-hal yang penting dipapan tulis dengan menggunakan spidol berwarna hitam, merah dan biru.

Guru menggunakan spidol dengan tiga warna karna hal ini bisa membuat siswa lebih tertarik memperhatikan yang disampaikan. Langkah ketiga yaitu pembagian kelompok, siswa duduk berdasarkan kelompok yang telah ditentukan sebelumnya yang terdiri 8 kelompok dengan rincian 7 kelompok terdiri dari 4 orang siswa dan satu kelompok lainnya terdiri dari 3 orang siswa. Langkah keempat yaitu diskusi, siswa berdiskusi membahas LKPD dan mempelajari materi yang telah disampaikan oleh guru dan siswa menanyakan hal-hal yang kurang dipahami kepada guru dan teman kelompok. Setelah siswa menyelesaikan LKPD maka guru meminta siswa untuk mengumpulkan semua LKPD kemudian guru menjelaskan penyelesaian dari permasalahan yang ada di LKPD.

Langkah selanjutnya yaitu talking stick, guru membagikan soal kepada masing-masing kelompok terdiri dari 4 soal. Masing-masing siswa menjawab satu soal yang telah ditentukan nomor pengerjaannya. Setelah waktu yang diberikan untuk mengerjakan soal berakhir maka guru memberikan tongkat kepada siswa (siswa pertama yang memegang tongkat diacak oleh guru agar semua siswa siap untuk menjawab soal) sambil diiringi musik instrumen (selama musik dibunyikan suasana kelas sangat hening, siswa mendengar musik dengan sangat cermat).

Ketika musik dihentikan maka siswa yang memegang tongkat harus mengerjakan soal didepan kelas. Kemudian siswa dipersilahkan duduk kembali dan tongkat kembali digulirkan sambil diiringi musik. Langkah ini dilakukan sampai 4 orang siswa mengerjakan soal dengan nomor berbeda. Namun jika siswa yang memegang tongkat memiliki nomor yang sama, jawaban siswa tersebut hanya dikumpulkan kepada guru tanpa menuliskan jawaban nya dipapan tulis. Hal ini dikarenakan keterbatasan sarana papan tulis. Selanjutnya guru bersama siswa membahas jawaban yang dikerjakan oleh teman-temannya dipapan tulis. Kemudian siswa diminta menulis jawaban yang benar dari pembahasan guru dan siswa dibuku catatan masing-masing, ini bertujuan agar siswa bisa belajar sesudah pembelajaran selesai. Langkah terakhir yaitu guru bersama siswa menyimpulkan materi yang telah dipelajari. Sebelum guru menutup pembelajaran guru memberikan pekerjaan rumah untuk siswa.

\section{Analisis Aktivitas Belajar}

Penelitian ini dilaksanakan sebanyak 12 pertemuan, yakni 6 pertemuan untuk kelas kontrol dan 6 pertemuan untuk kelas eksperimen. Untuk masing-masing kelas 5 pertemuan untuk proses belajar mengajar dan 1 pertemuan untuk posttest dapat dilihat jadwal mengajar pada lampiran 35. Dalam satu minggu siswa kelas VII di MTsN1 Kota Bengkulu belajar matematika sebanyak tiga kali. Setiap pertemuan ada yang terdiri dari 2 jam pelajaran dan 1 jam pelajaran dengan 
alokasi waktu 40 menit untuk setiap 1 jam pelajaran. Pada kelas eksperimen digunakan model pembelajaran talking stick dan kelas kontrol digunakan pembelajaran ekspositori. Pelaksanaan pembelajaran pada penelitian ini dilakukan pada materi aritmatika sosial.

Pada pertemuan pertama kelas eksperimen materi yang dipelajari siswa adalah keuntungan dan kerugian sesuai dengan RPP (Lampiran 6). Pembelajaran dibuka dengan salam dan do'a oleh semua siswa, guru mengecek kehadiran siswa dan menyampaikan bahwa materi aritmatika sosial memiliki banyak manfaat dalam kehidupan sehari-hari. Guru mengawali pembelajaran dengan memberikan apersepsi tentang harga beli dan harga jual suatu barang. Pada tahap ini guru memberikan sedikit gambaran mengenai materi pelajaran yang disampaikan dengan memberikan beberapa contoh yang berkaitan dengan kehidupan sehari-hari. Sebagai contoh, siswa diminta memberikan beberapa ilustrasi tentang jual beli, harga jual dan harga beli. Pertanyaan yang muncul pada saat siswa mengungkapkan contoh berdasarkan apa yang mereka pikirkan.

Seorang siswa mengungkapkan bahwa "di daerahnya ada penjual beras yang menjual beras dengan harga Rp. 150.000,- per karung isi $10 \mathrm{~kg}$. Namun warga sering membeli eceran kepada pedagang tersebut dengan harga $\mathrm{Rp}$. 16.000,- per kg". Dari ilustrasi ini muncul beberapa pertanyaan yang mampu memicu semangat belajar siswa sebagai berikut:

1. Berapa harga beli per karung beras tersebut oleh pedagang?

2. Berapa hasil yang akan di dapatkan oleh pedagang jika beras tersebut terjual eceran per $\mathrm{kg}$ ?

Pertanyaan demi pertanyan muncul dari satu pernyataan yang diungkapkan oleh siswa. Guru memberikan kesempatan kepada siswa lain untuk menjawab pertanyaan tersebut. Selanjutnya barulah guru menyampaikan apersepsi didepan kelas dan menuliskan hal-hal yang penting dipapan tulis dengan menggunakan spidol berwarna hitam, merah dan biru.
Guru menggunakan spidol dengan tiga warna karna hal ini bisa membuat siswa lebih tertarik memperhatikan yang disampaikan. Guru kemudian memberikan sebuah contoh agar siswa benar-benar paham tentang apa yang disampaikan dengan melontarkan pernyataan

"Dapatkah kalian menentukan harga jual dan harga beli jika seorang penjual buah membeli buah jeruk $10 \mathrm{~kg}$ dengan harga $\mathrm{Rp}$. 160.000,- kemudian menjual $10 \mathrm{~kg}$ jeruk tersebut dengan harga Rp.200.000,-?"

Pada tahap ini siswa aktif memberikan jawaban sehingga apersepsi tersampaikan dengan baik.

Guru menyiapkan tongkat dan musik, sebelum menjelaskan materi guru menjelaskan tahapan model pembelajaran talking stick. Setelah itu guru menjelaskan materi mengenai keuntungan dan kerugian dari masalah jual beli di depan kelas dengan menuliskan point-point pentingnya di papan tulis. Pada tahap ini siswa memperhatikan dengan seksama apa yang disampaikan oleh guru. Selanjutnya guru membagi siswa menjadi 7 kelompok dengan anggota setiap kelompok sebanyak 4 orang dan satu kelompok lainnya beranggotakan 3 orang sehingga berjumlah 8 kelompok dimana anggota setiap kelompok sudah disiapkan dan ditentukan oleh guru.

Masing-masing kelompok diberikan Lembar Kegiatan Peserta Didik (LKPD) yang berfungsi untuk mengarahkan siswa memahami lebih baik tentang materi yang telah disampaikan oleh guru. Setiap kelompok diberikan LKPD dan guru mengarahkan setiap kelompok untuk menyelesaikan permasalahan di LKPD melalui diskusi. Guru memastikan semua anggota kelompok memahami cara menyelesaikan LKPD dalam waktu 10 menit. Selanjutnya LKPD dikumpulkan dan guru menjelaskan tata cara penyelesaian permasalahan yang disajikan di LKPD di depan kelas. Dari hasil penyelesaian siswa diperoleh kesimpulan bahwa semua kelompok mampu menyelesaikan LKPD yang diberikan guru dengan tepat seperti hasil penyelesaian salah satu kelompok pada gambar 1. 


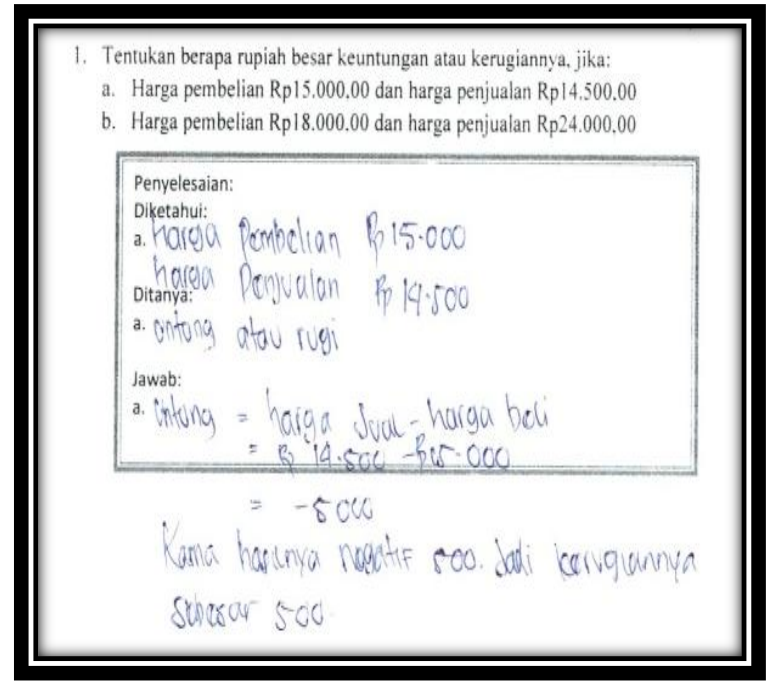

Gambar 1. Jawaban Siswa di LKPD I

Langkah selanjutnya yaitu talking stick, guru membagikan soal yang terdiri dari 4 soal kepada masing-masing kelompok. Artinya satu siswa dalam satu kelompok diminta menyelesaikan satu soal yang sudah ditentukan berdasarkan nomor urutannya dalam kelompok tersebut. Setelah waktu yang diberikan untuk mengerjakan soal berakhir. Selanjutnya setiap siswa harus siap memberikan jawaban terhadap soal yang dikerjakan. Disamping itu, guru memberikan tongkat kepada salah satu siswa (siswa pertama yang memegang tongkat diacak oleh guru agar semua siswa siap untuk menjawab soal) sambil diiringi musik instrument (selama musik dibunyikan suasana kelas sangat hening, siswa mendengar musik dengan sangat cermat).

Ketika musik dihentikan maka siswa yang memegang tongkat harus mengerjakan soal dipapan tulis. Guru menanyakan kepada siswa lain apakah jawaban mereka sama atau berbeda dengan apa yang ditampilkan oleh siswa tersebut. Jika terdapat jawaban yang berbeda maka jawaban akan disimpan dan guru tetap melanjutkan proses tongkat bergilir. Langkah ini dilakukan sampai 4 orang siswa mengerjakan soal dengan nomor berbeda.

Selanjutnya guru bersama siswa membahas jawaban yang dikerjakan oleh teman-temannya dipapan tulis namun sebelumnya kertas jawaban siswa dikumpulkan kepada guru. Kemudian siswa diminta menulis jawaban yang benar dari pembahasan guru dibuku catatan masing-masing agar siswa bisa belajar sesudah pembelajaran selesai. Namun jika siswa yang memegang tongkat memiliki nomor yang sama, jawaban siswa tersebut hanya dikumpulkan kepada guru tanpa menuliskan jawaban nya dipapan tulis. Hal ini dikarenakan keterbatasan sarana papan tulis. Selanjutnya guru bersama siswa membahas jawaban yang dikerjakan oleh teman-temannya dipapan tulis namun sebelumnya kertas jawaban siswa dikumpulkan kepada guru. Kemudian siswa diminta menulis jawaban yang benar dari pembahasan guru dibuku catatan masing-masing agar siswa bisa belajar sesudah pembelajaran selesai.

Langkah terakhir yaitu guru bersama siswa menyimpulkan materi yang telah dipelajari. Sebelum guru menutup pembelajaran guru memberikan pekerjaan rumah untuk siswa. Untuk pertemuan kedua sampai kelima dilakukan dengan tahap pembelajaran yang sama dengan materi yang dipelajari yaitu persentase untung dan rugi pada pertemuan kedua, diskon dan pajak pada pertemuan ketiga, bunga tunggal pada pertemuan keempat, bruto netto dan tara pada pertemuan kelima.

Peningkatan aktivitas belajar matematika dengan menggunakan model pembelajaran talking stick adalah sebagai berikut:

1. Sebagian besar siswa terlibat aktif dalam mengikuti proses pembelajaran dikelas

Siswa cenderung lebih pasif dalam mengikuti proses pembelajaran.

2. Siswa cukup aktif selama proses diskusi dan saling berbagi informasi tentang materi yang sedang dipelajari. Siswa hanya menerima materi yang disampaikan oleh guru.

3. Selama mengikuti proses tongkat bergulir diiringi musik siswa terlihat senang dan antusias dalam menjawab soal dan siswa berani mengemukakan pendapat dan menyimpulkan tentang materi yang telah dipelajari. Sehingga hanya sedikit siswa yang mampu mengingat dan memahami materi yang disampaikan oleh guru.

\section{PENUTUP \\ Simpulan}

Jadi dapat disimpulkan bahwa terjadi peningkatan aktivitas belajar siswa kelas VII MTs N1 Kota Bengkulu dengan menggunakan model pembelajaran talking stick. 


\section{Daftar Pustaka}

Hartanto, Suryo \& Sriyani. 2016. Pengaruh Model Pembelajaran Talking Stick Terhadap Hasil Belajar Matematika Siswa Kelas VIII SMP Negeri 11 Batam. Artikel: Pythagoras vol 5 No. 1

Huda, Miftahul. 2013. Model-Model Pengajaran dan Pembelajaran. Yogyakarta: Pustaka Pelajar

Lestari,Karunia E \& yudhanegara, mokhammad R. 2015. Penelitian Pendidikan Matematika. Bandung: Refika Aditama

Purwanto. 2011. Evaluasi Hasil Belajar. Yogjakarta: Pustaka Pelajar

Supriyanto, Agus. 2013. Cooperative Learning. Yogjakarta: Pustaka Pelajar

Susanto, Ahmad. 2014. Teori Belajar \& Pembelajaran di Sekolah Dasar. Jakarta: Kencana 